\title{
Nurses and care workers' perceptions of their nurse- patient therapeutic relationship in private general hospitals, Gauteng, South Africa
}

\author{
Authors: \\ Anna E. van den Heever ${ }^{1}$ \\ Marie Poggenpoel ${ }^{1}$ \\ Chris P.H. Myburgh ${ }^{1}$

\section{Affiliations: \\ ${ }^{1}$ Department of Nursing Science, Faculty of Health Sciences, University of Johannesburg, South Africa}

\section{Correspondence to:}

Anna van den Heever

Email:

annalie.vdheever@gmail.com

Postal address:

PO Box 1654, Pinegowrie

2123, South Africa

Dates:

Received: 11 Feb. 2013

Accepted: 01 July 2013

Published: 19 Sept. 2013

How to cite this article: Van den Heever, A.E., Poggenpoel, M. \& Myburgh, C.P.H., 2013, 'Nurses and care workers' perceptions of their nurse-patient therapeutic relationship in private general hospitals, Gauteng, South Africa', Health SA Gesondheid 18(1), Art. \#727, 7 pages. http:// dx.doi.org/10.4102/hsag. v18i1.727

\section{Copyright:}

(C) 2013. The Authors. Licensee: AOSIS OpenJournals. This work is licensed under the Creative Commons Attribution License.
Facilitation of a therapeutic relationship is an essential skill in nursing, particularly in mentalhealth care. Nurses and care workers in private general hospitals are exposed to the emotional effects of physical illness as well as the increase in admission of patients with mental-health needs. Poor nurse-patient relationships have been reported by patients and in the media. The researchers experienced incidents of apparent misunderstandings during nurse-patient interactions whilst working in private general hospitals. No studies have been done regarding how nurses and care workers perceive a therapeutic relationship with patients in terms of the patients' emotional and mental-health needs. A quantitative, contextual and deductive study was conducted in three private general hospitals in Gauteng, South Africa with a purposive sample of 154 nurses and 30 care workers. Based on the concepts of a therapeutic relationship, empathy, positive regard, genuineness, concreteness and self-exploration, nurses and care workers' perceptions of facilitating a therapeutic relationship were self-assessed using five-point scales in a questionnaire. Data were analysed using descriptive statistics and non-parametric statistical techniques. Specific hypotheses were tested to identify whether statistically-significant differences existed between the perceptions of two or more groups of nurses and care workers. Results showed a general insensitivity and lack of awareness and reflection on the part of nurses and care workers with regard to the patients' emotional needs. When categories of nurses were compared, no statistically-significant differences were found between the perceptions of the various groups tested. There is a need for self-awareness, continued interpersonal skills training and supervision of nurses and care workers. A large percentage of the participants were younger than 40 years, subprofessional, with less than 10 years' experience as nurses or care workers. Private general hospitals should therefore equip all nurses and care workers with the necessary skills to facilitate a therapeutic relationship and to understand the emotional needs of all patients with both physical and emotional needs.

Fasilitering van ' $n$ terapetiese verhouding is ' $n$ essensiële vaardigheid in verpleging en veral in geestesgesondheid. Verpleegkundiges in private algemene hospitale is blootgestel aan die emosionele gevolge van fisiese siekte asook die toenemende toelating van pasiënte met geestesgesondheidsbehoeftes. Swak verpleegkundige-pasiënt verhoudings is deur pasiënte en in die media gerapporteer, terwyl die navorsers van oënskynlike misverstande tydens interaksies tussen verpleegkundiges en pasiënte bewus geword het tydens hulle werk in private algemene hospitale. Geen studies is gedoen oor hoe verpleegkundiges en versorgers hulle terapeutiese verhouding met pasiënte in terme van hulle emosionele en geestesgesondheidsbehoeftes ervaar nie. 'n Kwantitatiewe, kontekstuele en deduktiewe studie was in drie private algemene hospitale in Gauteng, Suid Afrika gedoen, met 'n doelgerigte steekproef van 154 verpleegkundiges en 30 versorgers. Verpleegkundige persepsies van die fasilitering van 'n terapeutiese verhouding gebaseer op die konsepte van 'n terapeutiese verhouding, empatie, positiewe agting, opregtheid, konkreetheid en selfondersoek is met selfassessering op 'n vyf-punt skaal van 'n vraelys bepaal. Data was geanaliseer met beskrywende statistieke en nie-parametriese tegnieke. Spesifieke hipoteses was getoets om te identifiseer of daar statistiese-betekenisvolle verskille tussen twee of meer kategorieë van verpleegkundiges bestaan. Resulte dui op ' $n$ algemene ongevoeligheid en lae bewustheidsvlak en refleksie van verpleegkundiges en versorgers ten opsigte van die pasiënte se emosionele behoeftes. Geen statistiese-betekenisvolle verskille is tussen die persepsies van die verskillende groepe in die navorsing gevind nie. Daar is ' $n$ behoefte aan self-gewaarwording en voortdurende opleiding in interpersoonlike vaardighede en ondersteuning aan verpleegkundiges en versorgers. 'n Groot persentasie van die deelnemers was jonger as 40 jaar, sub-professioneel, met minder as 10 jaar ondervinding as verpleegkundiges. Private algemene hospitale moet dus alle verpleegkundiges en versorgers toerus met die nodige vaardighede om 'n terapeutiese verhouding te fasiliteer om al hulle pasiënte se fisiese en emosionele behoeftes te verstaan. 


\section{Background}

With the promulgation of the Mental Health Care Act, 17 of 2002 (Republic of South Africa 2002) in South Africa, nurses and care workers working in private general hospitals have been exposed to increasing challenges of dealing with patients who have not only physical and emotional needs, but also mental-health disorders. Such disorders are conditions affecting the mental state of a person to such an extent that it causes significant distress to the person and/ or challenges the person's ability to function in terms of their self-care (Mental Health Care Act, 17 of 2002) (Republic of South Africa 2002).

Private hospitals are institutions or facilities where persons receive care, treatment and rehabilitative assistance as well as diagnostic or therapeutic interventions at a regulated fee for service, according to the National Health Act, 61 of 2003 (Republic of South Africa 2003:12). Nurses, on the other hand, who are employed in a private general hospital, should be qualified and competent to practise nursing in the manner and to the level prescribed by the South African Nursing Council (Regulation No. 2598 of 30 November 1984) (South African Nursing Council 1984). Care workers, who have had no formal training in a nursing college or university, are employed regularly for financial or operational reasons in order to assist with elementary care of patients in private general hospitals. Nonetheless, a qualification which includes training in recognising mental health needs has not been a prerequisite for the employment of nurses and care workers who are working in general hospitals.

Irrespective of the qualification, facilitation of a therapeutic nurse-patient relationship has always been the cornerstone of nursing and includes self-knowledge and knowledge about the essential components of therapeutic communication. These components include unconditional acceptance of the patient, the ability to listen and to hear, constructive nonverbal skills and verbal communication techniques. The use of rapport and alliance enables this process to happen by providing support, consistency and reliability in patient care (Gilbert 2009).

Nurses are expected to show empathy, positive regard and respect to all patients, but the bureaucratic environment in private general hospitals is driven by technology and a mainly medical model of care, making a therapeutic relationship between nurses or care workers and their patients difficult.

\section{Problem statement}

Poor nurse-patient relations which were reported in the media (Van Zyl 2011:94) were encountered in a private general hospital when patients expressed their dissatisfaction with nurses who seemed to behave unsympathetically toward their emotional needs. When questioned by the researchers, the nurses and care workers were surprised with their patients' reactions and seemed unaware of the effect that their responses have on patients, irrespective of the previous training they had received (Van den Heever 2012:3). The negative effects of these shortcomings on nurses and patient outcomes have been described by several authors (Moyle 2003:103; Vythilingum 2009:450) and fear of saying the 'wrong thing' has resulted in people receiving limited mental-health care from nurses working in a general hospital (Reed \& Fitzgerald 2005:255). Furthermore, in a study by McEnhill (2008:160), most patients with mild intellectual disabilities had either not received or understood the bad news given to them about their chronic illness.

\section{Research aim and objectives}

Perception is the ability to see, hear or become aware of something through the senses (Bozarth 2001). In accordance with the research problem, the aim of the study was to explore and describe nurses and care workers' perceptions of facilitating a nurse-patient therapeutic relationship.

The research objectives were:

- To explore and describe nurses and care workers' perceptions of facilitating a therapeutic relationship when caring for patients with physical, emotional and/or mental-health challenges.

- To examine differences in nurses and care workers' perceptions of facilitating a therapeutic relationship empirically by comparing groups according to gender, age, years of experience, qualifications and interpersonal skills training.

- To propose recommendations concerning the facilitation of a therapeutic relationship with the patient for all nurses and care workers working in private general hospitals.

\section{Conceptual framework for research: Therapeutic relationship Components of a therapeutic relationship}

Nurses and other healthcare workers need a special set of therapeutic communication skills to deal with the emotional challenges of patients, such as active listening as well as constructive verbal and non-verbal affective techniques. Empathetic understanding, respect and transparency contribute to self-exploration and a nurse-patient therapeutic relationship based on trust (Arnold \& Boggs 2011:19; Frisch \& Frisch 2011:102; Gilbert 2009:307)

Carl Rogers' person-centred concepts of a therapeutic relationship and a systematic approach to the evaluation of interpersonal relationships were used in the theoretical framework of this study (Aiken \& Aiken 1973:865; Rogers 1957:100). Within the nurse-patient therapeutic relationship the nurse is expected to behave in a certain way by facilitating empathy, positive regard, genuineness, concreteness and self-exploration on various levels. The interactive nursepatient relationship could be facilitated on any of five levels (I to V). At the lower levels of facilitation (I and II), the nurse requires basic concern and empathetic understanding for the patient's feelings. At level III, a response neither facilitates nor hinders a therapeutic relationship. At the higher levels 
(IV and V), the nurse requires awareness of the patient's deepest emotions, allowing them to explore their illness and experience empathy and respect as individuals (Aiken \& Aiken 1973:865). The level at which nurses communicate is detrimental to the promotion, maintenance and restoration of the patient's health (Poggenpoel 1997:32). The perception of each other in an open and trusting relationship is established when the patient is treated with respect, as an equal and a human being, by the care giver (Bozarth 2001).

The concepts of a therapeutic relationship are interlinked. Empathetic understanding exists when the nurse reflects to a patient her ability to put herself in that patient's shoes. Attention is thus focused on the acceptance of the patients' experiences rather than on only talking to them (Bozarth 2001). Unconditional positive regard means unqualified respect for one another, irrespective of how painful or pleasurable one's feelings might be. Withholding of care or love because of disregard for the patient can therefore be seen as being harmful (Wilkens 2000:24). A genuine and authentic response can be communicated when a nurse has the ability to identify similarities and differences between facial expressions and behaviour of the patient. When patients experience honest and congruent responses from others, they are able to manage uncertainty and make decisions for themselves (Epstein \& Street 2007:17). That being said, it follows that a person's beliefs about himself and the world, as well as spiritual and moral-ethical conduct, are linked closely to 'genuineness' (LaSala 2009:429).

Patients expect understanding of their situation. Feedback from health professionals in the form of vague and abstract messages, or no concrete feedback at all, hinders communication. The decision as to whether feedback or the timing thereof is appropriate depends on whether it will advance the goals of the relationship (Arnold \& Boggs 2011:191). Finally, patients would be more open to self-exploration and would share personally-relevant information or feelings when they felt understood, respected and accepted as individuals.

\section{Personal attributes that influence facilitation of a therapeutic nurse-patient relationship}

Knowledge, skills and attitude are required to enter into a relationship with a patient. Not only do nurses and care workers who work in general wards lack training in establishing relationships, but they also experience inadequate knowledge and supervision (Harrison \& Zohhadi 2005:476; Mavundla 2000:1574). In South Africa the Nursing Act, 33 of 2005 (Republic of South Africa 2005) makes provision for the education, training, research, registration and practice of nurses, who have to register or enrol with the South African Nursing Council. Various categories of nurses and care workers are employed in private general hospitals. These individuals were trained at either a nursing college, university or a care facility which offered various courses allowing them to become registered nurses, enrolled nurses, enrolled auxiliary nurses or care workers.
Negative attitudes toward patients' emotional needs and their environment could cause fear and despair which could then affect nurses' perceptions of themselves and others (Harrison \& Zohhadi 2005:475; Mavundla 2000:1573; Reed \& Fitzgerald 2005:254). Perception, in other words, is the ability to see, hear or become aware of something through the senses (Bozarth 2001), and is related closely to attitude. Attitude thus refers to the perception or opinion one holds about others and also toward aspects such as life and death. It can also be viewed as a mind-set and the tendency to act in a particular way, as a result of an individual's culture, experience and temperament (Pickens 2005:44). If nurses give incongruent verbal and non-verbal messages which in turn reflect their negative attitude, patients could experience the interaction as being threatening and stigmatising behaviour (Andrews, Henderson \& Hall 2001:145).

\section{Factors that influence facilitation of a therapeutic relationship with a patient}

A supportive psychiatric therapeutic environment is geared toward the mental-health needs of patients. In terms of the Mental Health Care Act, 17 of 2002 (Republic of South Africa 2002), private general hospitals in South Africa are in the practice of admitting patients with mental-health disorders to the general wards. The therapeutic environment in these hospitals may be influenced by various factors that may support or limit the facilitation of a therapeutic nurse-patient relationship. Drug and alcohol use, domestic and public violence, suicide attempts and the prevalence of HIV pose major management problems for hospitals in South Africa. Then again, diagnosis of mental illness itself could have an effect on how patients perceive their relationships with nurses (Bjørngaard, Ruud \& Friis 2007:804) and vice-versa.

The changing patient profile and burden of care are aggravated when mental-health disorders such as depression, delirium or post-natal psychosis coexist with medical or surgical conditions (Vythilingum 2009:450). The strategic policy in South Africa to admit patients with mental-health disorders to general wards, even if temporarily, further challenges the competencies of nurses, especially when there is already a shortage of professional nurses (specifically, trained psychiatric nurses) in South Africa (Weltman 2007:7). The focus of care in private general hospitals is on the medical and curative model. Therapeutic interventions are at a regulated fee for service which results in task allocation and nurses spending less time with the patient. Consequently, as a common cost-containment strategy, basic patient care is rendered mainly by subprofessional nurses (Hanrahan \& Aiken 2008:215; Reed \& Fitzgerald 2005:251) and care workers.

\section{Research design and method}

A quantitative, contextual and deductive design, using a questionnaire, was carried out amongst nurses and care workers working in three private general hospitals in Gauteng, South Africa. Existing instruments were not appropriate or applicable to nurses in the context of this 
study. A 25-item self-assessment questionnaire was designed and validated by specialists in the field in order to assess nurses and care workers' perceptions regarding facilitating a therapeutic relationship.

\section{Questionnaire}

Part A of the questionnaire consisted of five questions regarding biographical data: gender, age, nursing qualifications, years' experience as a nurse and previous interpersonal skills-training courses attended. Part B comprised scenarios to examine a nurse-patient interaction on various levels (I to V) of facilitation (Aiken \& Aiken 1973:865) based on the concepts of a therapeutic relationship: empathy, positive regard, genuineness, concreteness and self-exploration. Participants were asked to rate each of the responses on a five-point scale by assessing their perception regarding facilitating a therapeutic nurse-patient relationship. The rating scale ranged from 'not at all' (1) to 'to a large extent' (5). A total of 25 response items was assessed (five response levels $\mathrm{x}$ five scenarios).

\section{Validity and reliability}

Content validity in this study was based on the extent to which the questions in the questionnaire and the scores obtained from the participants are representative of the possible questions that a researcher could ask about the content or concepts being measured (Creswell 2008:172). The questions were based on theory and formulated in view of existing literature. A pilot study was conducted amongst nurses and care workers working in another hospital of the same private healthcare group so as to test the practicability of the research instrument. Content validity was further ensured by experienced specialists in the fields of nursing and educational research who examined the questionnaire (Botes 2005:191).

The Cronbach's alpha coefficient was used to estimate the internal consistency of the questionnaire (Polit \& Beck 2008:751). Considering the explorative nature of the investigation and the number of items in the questionnaire, reliability was acceptable within the limited scope of the study: (0.688) items which lack concern for patients' feelings; (0.673) superficial items; (0.571) items which neither facilitate nor hinder a therapeutic relationship; (0.591) items which add deeper meaning; and (0.695) items which are reflective of patients' feelings (Van den Heever 2012:45).

\section{Ethical considerations}

In accordance with ethical measures (Dhai \& McQuoidMason 2011:14), the procedure was explained and participants were given the opportunity to read the covering letter. Completion of the questionnaire was considered as being consent to voluntary participation. The participants were reassured of beneficence, non-maleficence, anonymity and confidentiality. No personal identification was required and the questionnaires were coded for statistical purposes. Once ethical approval and permission from the University of Johannesburg and from the private hospital authorities was obtained, (AEC24/01-2011) the data-collection process was repeated at three private hospitals. Questionnaires were distributed to nurses and care workers on all shifts, for example, day and night shift, for all seven days of the week. Patient care was a priority and had to be considered when nurses were called to participate. Nurses from operation theatres and intensive care units were excluded. Questionnaires took 20-30 minutes to complete. A total of 240 questionnaires was distributed and participants were asked to place completed questionnaires in a sealed box which was collected after two hours by the researcher.

Data were analysed using the SPSS version 18 statistical software package. A variety of statistical analyses was applied to the data, including Kolmogorov-Smirnov, Student's $t$-test, Mann-Whitney U and Kruskal-Wallis non-parametric tests. Characteristics of nurses and care workers were described whilst inferential statistics were utilised in order to compare groups, test hypotheses and make deductions from the data (Polit \& Beck 2008:752). Based on the objectives of the study, the following null hypothesis $\left(\mathrm{H}_{0}\right)$ was tested: 'There is no statistically-significant difference between specific groups of nurses and care workers' perceptions of the levels of facilitation of a therapeutic relationship'. The alternative hypothesis $\left(\mathrm{H}_{\mathrm{a}}\right)$ was as follows: 'There is a statisticallysignificant difference between specific groups of nurses and care workers' perceptions of the levels of facilitation of a therapeutic relationship'.

\section{Research results}

There were 184 nurses and care workers who participated in the study: $33.7 \%(n=62)$ were registered nurses and $10.9 \%$ $(n=20)$ were registered nurses with a psychiatric qualification. Other categories consisted of $21.7 \%(n=40)$ enrolled nurses, $17.4 \%(n=32)$ enrolled auxiliary nurses and $16.3 \%(n=30)$ care workers.

Descriptive analysis of the biographical data obtained from the sample indicated that $92.4 \%$ of the participants were women $(n=170) ; 53.3 \%$ were younger than 40 years of age $(n=103)$ and $43.7 \%$ were older than 40 years $(n=80)$, with a mean age of 38.58 years; $52 \%$ had less than 10 years' experience $(n=96)$ and $47.3 \%$ had more than 10 years' experience $(n=87)$, giving a mean of 9 years. A basic interpersonal skills-training course had previously been attended by $51.1 \%$ $(n=92)$ of the participants, an advanced course by $18.3 \%$ $(n=33)$ and $30.6 \%(n=55)$ of the participants had no skills training whatsoever. For statistical purposes, nursing qualifications were collapsed into two groups: (1) the professional group, namely registered nurses with or without psychiatric qualifications $(44.6 \% ; n=82)$ and (2) the subprofessional group $(55.4 \% ; n=102)$, comprising enrolledand auxiliary nurses and care workers (Van den Heever 2012:42).

Nurses and care workers' perceptions were assessed (Figure 1) regarding the level on which a therapeutic 
relationship is facilitated (Aiken \& Aiken 1973:866). The levels were operationalised in the questionnaire by means of responses to patients as described in interactive scenarios related to the characteristics of a therapeutic relationship (Van den Heever 2012:29).

Perceptions of various categories of nurses and care workers were further compared and specific hypotheses were tested

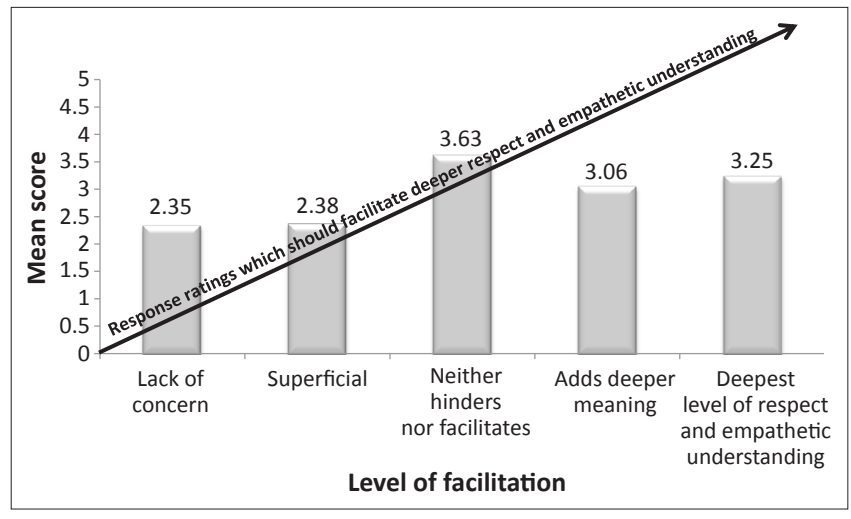

FIGURE 1: A summary of nurses and care workers' self-assessed perception rated on a scale from 'not at all' (1) to 'to a large extent' (5). by means of non-parametric statistical techniques. The null hypothesis $\left(\mathrm{H}_{0}\right)$ stating that there is no statistically-significant difference in nurses and care workers' perceptions when specific nurse groups were compared was rejected if the $p$-value was less than a $0.05(5 \%)$ or $0.01(1 \%)$ level of significance. Statistical differences in nurses and care workers' perceptions were identified when groups of nurse-categories were compared regarding several of the 25 response items (see Tables 1-3).

Although statistically-significant differences in some of the 25 response items were identified (Tables 1-3), further inspection of the size differences between the mean or rank orders of the two compared groups revealed that the differences were not substantial. The alternative hypothesis $\left(\mathrm{H}_{\mathrm{a}}\right)$ 'there is a statistically significant difference between specific groups of nurses and care workers' perception of the levels of facilitation of a therapeutic relationship' could therefore not be accepted.

\section{Discussion of the results}

Perceptions of nurses and care workers, in other words, the ability to see, hear or become aware of something through

TABLE 1: Nurses and care workers' perceptions based on age and year's experience, tested with the student's $t$-test.

\begin{tabular}{|c|c|c|c|c|c|c|c|}
\hline \multirow{2}{*}{$\begin{array}{l}\text { Statistical differences on response } \\
\text { items identified of facilitation }\end{array}$} & \multirow[t]{2}{*}{ Level } & \multirow{2}{*}{$\begin{array}{c}\text { Younger than } 40 \text { years } \\
M\end{array}$} & \multirow{2}{*}{$\frac{40 \text { years and older }}{M}$} & \multirow[t]{2}{*}{$p$-value } & \multirow{2}{*}{$\begin{array}{c}\text { Less than } 10 \text { years } \\
\mathrm{M}\end{array}$} & \multirow{2}{*}{$\frac{10 \text { or more years }}{\mathrm{M}}$} & \multirow[t]{2}{*}{$p$-value } \\
\hline & & & & & & & \\
\hline \multirow{3}{*}{$\begin{array}{l}\text { Responses which lack concern and } \\
\text { are superficial. }\end{array}$} & 1 & - & - & - & 3.10 & 2.29 & $0.000 * *$ \\
\hline & 2 & - & - & - & 3.47 & 3.00 & $0.035^{*}$ \\
\hline & & 2.56 & 3.01 & $0.044^{*}$ & - & - & - \\
\hline $\begin{array}{l}\text { Responses do not hinder nor } \\
\text { a relationship. }\end{array}$ & 3 & 3.72 & 4.16 & $0.022^{*}$ & - & - & - \\
\hline \multirow{4}{*}{$\begin{array}{l}\text { Responses add deeper meaning } \\
\text { and are reflective of patients' } \\
\text { feelings. }\end{array}$} & 4 & 1.87 & 2.56 & $0.001^{* *}$ & 1.97 & 2.40 & $0.032 *$ \\
\hline & 5 & 3.10 & 3.88 & $0.000 * *$ & 3.11 & 3.79 & $0.001 * *$ \\
\hline & & 2.60 & 3.38 & $0.001 * *$ & 2.62 & 3.30 & $0.002 * *$ \\
\hline & & 2.98 & 3.59 & $0.004^{* *}$ & - & - & - \\
\hline
\end{tabular}

$\mathrm{M}$, mean score.

$*, 5 \%$ statistical significance; ${ }^{* *}, 1 \%$ statistical significance.

TABLE 2: Perceptions of two pairs of nurses and care workers who attended basic interpersonal skills-training compared to those who attended advanced training courses, tested with the Mann-Whitney U test.

\begin{tabular}{|c|c|c|c|c|c|}
\hline \multirow{2}{*}{$\begin{array}{l}\text { Previous skills training course } \\
\text { attended }\end{array}$} & \multicolumn{2}{|c|}{ Basic training } & \multicolumn{2}{|c|}{ Advanced training } & \multirow{2}{*}{$\begin{array}{l}\mathrm{U} \text {-value } \\
p \text { - }\end{array}$} \\
\hline & M & Rank & M & Rank & \\
\hline Level 1 responses which lack concern for the patient's feelings. & 3.08 & 57.84 & 3.75 & 73.84 & $0.025^{*}$ \\
\hline Level $1 \mathrm{~V}$ responses which add deeper meaning. & 3.86 & 67.16 & 3.03 & 49.11 & $0.010 * *$ \\
\hline
\end{tabular}

Level $1 \mathrm{~V}$ responses which add deeper meaning.

3.86

67.16

3.03

*, $5 \%$ statistical significance; **, Tested against 0.0167 (0.05/3) level of significance (Bonferonni adjustment).

TABLE 3: Perceptions of professional compared to the sub-professional nurse groups, tested with the Mann-Whitney $U$ test.

\begin{tabular}{|c|c|c|c|c|c|c|}
\hline \multirow[t]{2}{*}{ Statistical differences on response of facilitation } & \multirow[t]{2}{*}{ Levels } & \multicolumn{2}{|c|}{ Professional } & \multicolumn{2}{|c|}{ Sub-professional } & \multirow[t]{2}{*}{$p$-value } \\
\hline & & M & Rank & M & Rank & \\
\hline \multirow{6}{*}{$\begin{array}{l}\text { Responses which are superficial and lack concern for the } \\
\text { patient's feelings. }\end{array}$} & \multirow[t]{4}{*}{1} & 1.56 & 83.34 & 2.08 & 98.20 & $0.027^{*}$ \\
\hline & & 2.44 & 82.69 & 2.91 & 97.74 & $0.048^{*}$ \\
\hline & & 1.96 & 77.59 & 2.68 & 101.06 & $0.001^{* *}$ \\
\hline & & 3.64 & 100.67 & 3.11 & 83.17 & $0.021^{*}$ \\
\hline & \multirow[t]{2}{*}{2} & 1.48 & 83.16 & 1.96 & 99.17 & $0.019 *$ \\
\hline & & 2.96 & 82.1 & 3.47 & 99.03 & $0.027^{*}$ \\
\hline Responses do not hinder nor facilitate a relationship. & 3 & 3.96 & 101.04 & 3.36 & 82.87 & $0.016^{*}$ \\
\hline \multirow{2}{*}{$\begin{array}{l}\text { Responses add deeper meaning and are reflective } \\
\text { of the patient's feelings. }\end{array}$} & \multirow[t]{2}{*}{4} & 3.79 & 104.66 & 3.16 & 82.72 & $0.004 * *$ \\
\hline & & 3.30 & 103.00 & 2.66 & 81.28 & $0.005^{* *}$ \\
\hline
\end{tabular}


the senses (Bozarth 2001), were self-assessed. The researchers hypothesised that there is no statistically-significant difference between specific groups of nurses and care workers' perceptions regarding facilitation of a therapeutic relationship, despite their knowledge, skills and experience.

Analysis of the results revealed that there was no reason to reject the hypothesis of the study and that the variables of age, qualifications, years' experience as a nurse or care worker and previous interpersonal skills-training did not play a significant role in the way in which nurses and care workers perceived a therapeutic relationship.

Patients as well as management expect quality customer care by knowledgeable and skilled nurses. Above all, there is an expectation that nurses should be able to show and communicate a deeper emotional level of empathic understanding and respect. In contrast to the expectation, the results of the study (Figure 1) show that most nurses and care workers perceived their facilitation at a level that is superficial and lacks concern for the patient's emotional needs.

Of concern is that the higher mean scores on level III (Figure 1) indicate that most nurses and care workers perceived the nurse-patient relationship as being a task. Performing these tasks is not only familiar to their practice and training but also evident of the medical model of care in private general hospitals. Nurses tend to reassure and give advice from within their own frame of reference, and also attempt to explain or moralise, but fail to address the patients' fears at an empathetic level (Poggenpoel 1997:30).

In one of the scenarios a male patient in a busy ward points to his urinary catheter and says: 'It hurts "down there" but I do not want the "whole world" to look at meagain'. The following practical response on level III neither hinders nor facilitates understanding of the patient's need for privacy and respect: 'Don't worry, Sir; I will make sure that the curtain is drawn when we check it out', but was rated highly by all nurses and care workers in the sample (Van den Heever 2012). Nurses and care workers' perceptions of response items on the levels of deeper empathetic understanding were rated lower than expected and indicate that most of the participants did not reflect awareness of the patients' emotional needs.

The findings also highlight the need for training and supervision of staff because the majority of participating nurses and care workers from three private general hospitals in Gauteng were female, younger than 40 years of age, had less than 10 years' experience and were from a subprofessional group. Interpersonal skills were clearly not retained over time, despite previous training or experience.

It is worrying that nurses perceived themselves as being insensitive, confirming patients' allegations, both historically and in the today's media, that nurses and care workers lack an awareness of patients' emotional needs.

\section{Limitations of the research}

Nurses and care workers from only three private general hospitals participated in the research and the results can thus not be generalised to other private and provincial hospitals. The influence of culture or language on facilitation of a therapeutic relationship was not explored and competence and knowledge were also not tested for in this study. In the light of the cultural diversity of patients and nursing staff in South Africa, further research into the cultural effects on the facilitation of a therapeutic relationship is suggested.

\section{Recommendations}

The findings of this study highlighted the importance of a nurse-patient relationship and the need to decrease incidents of distress and misunderstanding in private general hospitals. The focus should be on all categories of nurses and care workers, irrespective of previous training, who might be at risk of being ill-equipped to deal with the increasing challenges of patients' mental-health needs.

Training should be aimed at bridging the gap between a level of facilitation that lacks concern for the patient's feelings and a level that is reflective and understanding of patients' emotions. A training task is to practise communication skills under the supervision of experienced professionals by means of experiential, interactive and continued training programmes. Not only is assessment of competence recommended, but self-awareness and reflection of nurses and care workers' own feelings are important in changing their perceptions regarding all patients and their mentalhealth needs.

The changing profile of patients as well as cost-containment measures contribute to the non-therapeutic environment in general wards. An investigation should be conducted in order to find ways in which to develop a therapeutic environment where physical and emotional needs of patients can be met: an environment where professional and subprofessional nurses have the time and opportunity to facilitate a therapeutic relationship with all patients.

\section{Conclusion}

Nurses play a notably important role in facilitating a therapeutic relationship. This study revealed that nurses and care workers, despite existing experience and training, are unaware of the verbal or non-verbal emotional messages of patients. Facilitation of such a relationship lacks deeper empathetic understanding, positive regard, genuineness and self-exploration, which contributes to misunderstandings and unhappiness in the nurse-patient therapeutic relationship.

\section{Acknowledgements}

The authors would like to thank the management of the private health hospitals and the research participants for their valuable input. 


\section{Competing interests}

The authors declare that they have no financial or personal relationship(s) which may have inappropriately influenced them in writing this article.

\section{Authors' contributions}

A.v.d.H. (University of Johannesburg) was the Masters candidate that conducted the research. M.P. (University of Johannesburg) supervised the conduct of the project and C.P.H.M. (University of Johannesburg) was a joint supervisor of the dissertation.

\section{References}

Aiken, L. \& Aiken, J.L., 1973, 'A systematic approach to the evaluation of interpersonal relationships', American Journal of Nursing 73(5), 863-867.

Andrews, G., Henderson, S. \& Hall, W., 2001, 'Prevalence, co-morbidity, disability and service Utilisation', The British Journal of Psychiatry 178(2), 145-153. http:// dx.doi.org/10.1192/bjp.178.2.145

Arnold, E.C. \& Boggs, K.U., 2011, Interpersonal relationships: professional communication skills for nurses, 6th edn., Elsevier, St. Louis, Missouri.

Bjørngaard, J.H., Ruud, T. \& Friis, S., 2007, 'The impact of mental illness on patient satisfaction with the therapeutic relationship', Social Psychiatry \& Psychiatric Epidemiology 42(10), 803-809. http://dx.doi.org/10.1007/s00127-007-0229-5

Botes, A., 2005, 'Validity, reliability and trustworthiness', in D. Rossouw (ed.), Intellectual tools: skills for the human sciences, pp.190-196, Amabhuku Publications. Pretoria.

Bozarth, J.D., 2001, 'Forty years of dialogue with the Rogerian Hypothesis', viewed 03 May 2011, from http://personcentered.com/dialogue.htm

Creswell, J.W., 2008, Educational research: planning, conducting, and evaluating quantitative and qualitative research, 3rd edn., Pearson Education, New Jersey.

Dhai, A. \& McQuoid-Mason, D., 2011, Bioethics, human rights and health law: principles and practice, Juta, Cape Town.

Epstein, R.M. \& Street, R.L. Jr., 2007, 'Patient-centered communication in cancer care: promoting healing and reducing suffering', National Cancer Institute (NIH Publication No. 07-6225), U.S. Department of Health and Human Services, Bethesda, viewed 20 January 2012, from http://outcomes.cancer.gov/areas/pcc/ communication/pcc_monograph.pdf

Frisch, N.C. \& Frisch, L.E., 2011, Psychiatric mental health nursing, 4th edn., Delmar, Albany, N.Y.

Gilbert, S.B., 2009, Psychiatric crash cart treatment strategies for the emergency department, Advanced Emergency Nursing Journal 31(4), 298-308, viewed 10 February 2012, from http://www.nursingcenter.com/library/JournalArticle. asp?Article_ID=942591

Hanrahan, N.P. \& Aiken, L.H., 2008, 'Psychiatric nurse reports on the quality of psychiatric care in general hospitals', Quality Managed Health Care 17(3), 210217. http://dx.doi.org/10.1097/01.QMH.0000326725.55460.af
Harrison, A. \& Zohhadi, S., 2005, 'Professional influences on the provision of mental health care for older people within a general hospital ward', Journal of Psychiatric and Mental Health Nursing 12(4), 472-480. http://dx.doi.org/10.1111/j.1365and Mental Health Nursing 12(4),

LaSala, C.A., 2009, 'Moral accountability and integrity in nursing practice', Nursing Clinics of North America 44(4), 423-434. http://dx.doi.org/10.1016/j.cnur.2009.07.006, of North America

Mavundla, T.R., 2000, 'Professional nurses' perception of nursing mentally ill people in a general hospital setting', Journal of Advanced Nursing 32(6), 1569-1578. http:// a general hospital setting', Journal of Advanced Nursing 32(6), $1569-13$.
dx.doi.org/10.1046/j.1365-2648.2000.01661.x, PMid:11136427

McEnhill, L., 2008, 'Breaking bad news of cancer to people with learning disabilities', British Journal of Learning Disabilities 36(3), 157-164. http://dx.doi.org/10.1111/ j.1468-3156.2008.00517.x,

Moyle, W., 2003, 'Nurse-patient relationship: A dichotomy of expectations', International Journal of Mental Health Nursing 12(2), 103-109. http://dx.doi. org/10.1046/j.1440-0979.2003.00276.x, PMid:12956021

Pickens, J., 2005, 'Attitudes and perceptions', in N. Borkowski (ed.), Organizationa Behaviour in Health Care, pp. 43-76, Jones and Bartlett Publishers, Sudbury, MA.

Poggenpoel, M., 1997, 'Nurses' responses to patients' communication', Curationis 20(3), 26-32. PMid:9496034

Polit, D.F. \& Beck, C.T., 2008, Nursing research: generating and assessing evidence for nursing practice, 8th edn., Lippincott Williams \& Wilkins, Philadelphia.

Reed, F. \& Fitzgerald, L., 2005, 'The mixed attitudes of nurses to caring for people with mental illness in a rural general hospital', International Journal of Mental Health Nursing 14(4), 249-257.

Republic of South Africa, 2002, Mental Health Care Act, No. 17 of 2002, Government Gazette No. 24024, Government Printer, Cape Town.

Republic of South Africa, 2003, National Health Act, No. 61 of 2003, Government Gazette No. 26595, Government Printers, Pretoria.

Republic of South Africa, 2005, The Nursing Act, No. 33 of 2005, Government Gazette No. 28883, Government Printers, Pretoria.

Rogers, C.R., 1957, 'The necessary and sufficient conditions of therapeutic personality change', Journal of Consulting Psychology 21(2), 95-103. http://dx.doi.org/10.1037/ h0045357, PMid:13416422

South African Nursing Council, 1984, 'Regulations relating to the Scope of Practice of Persons who are Registered or Enrolled under the Nursing Act, 1978', Government Notice No. R.2598 of 30 November 1984, viewed 7 July 2013, from http://www. sanc.co.za/regulat/Reg-scp.htm

Van den Heever, A.E., 2012, 'Nurses' own perception of their therapeutic relationship in providing care to patients with mental health disorders', unpublished Masters Dissertation, Department of Nursing Science, University of Johannesburg.

Van Zyl, G., 2011, 'A discourse and content analysis of how nursing is framed in the mainstream press in South Africa: January-June 2010', Master's thesis, Centre of Health Policy, School of Public Health, University of the Witwatersrand.

Vythilingum, B., 2009, 'Anxiety disorders in pregnancy and the postnatal period', Continuing medical education (CME) October 2009, 27(10):450-452.

Weltman, N., 2007, The HASA chairperson's report 2007-2008, HASA News, 07 October 2007, Hospital Association of South Africa, monthly publication.

Wilkens, P., 2000, 'Unconditional positive regard reconsidered', British Journal of Guidance \& Counselling 28(1), 23-36. http://dx.doi.org/10.1080/030698800109592 